\title{
PERANAN BADAN USAHA MILIK NEGARA DALAM PEMBANGUNAN KEMARITIMAN
}

(The Role of the State-Owned Enterprises on Maritime Development)

\author{
Muhammad Insa Ansari \\ Fakultas Hukum Universitas Syiah Kuala \\ Jalan Putroe Phang No.1 Darussalam, Banda Aceh \\ E-mail: insa.ansari@unsyiah.ac.id
}

Naskah diterima: 25 April 2019; revisi: 23 Juli 2019; disetujui: 2 Agustus 2019

\begin{abstract}
Abstrak
Pembangunan nasional yang dilaksanakan oleh negara meliputi seluruh aspek kehidupan berbangsa dan bernegara, termasuk pembangunan kemaritiman. Dalam melaksanakan pembangunan kemaritiman, negara mendayagunakan seluruh komponen yang dimiliki, termasuk mendayagunakan Badan Usaha Milik Negara. Artikel ini membahas kedudukan Negara di bidang pelayaran dalam kaitannya dengan pembangunan kemaritiman dan peranan Badan Usaha Milik Negara bidang pelayaran dalam pembangunan kemaritiman. Untuk menjawab permasalahan tersebut, penelitian ini dilakukan dengan menggunakan metode penelitian hukum normatif. Dalam penelitian hukum normatif ini digunakan bahan hukum primer, bahan hukum sekunder, dan bahan hukum tersier. Hasil penelitian menunjukan penguasaan negara atas pelayaran diperankan oleh pemerintah dalam bentuk pengaturan, pengendalian, dan pengawasan. Selain itu pemerintah memberikan penugasan kewajiban pelayanan umum kepada Badan Usaha Milik Negara. Penugasan yang diemban Badan Usaha Milik Negara tersebut memiliki arti penting dalam pembangunan kemaritiman. Menariknya, kewajiban pelayanan umum yang diemban Badan Usaha Milik Negara bidang pelayaran berkorelasi positif dengan maksud dan tujuan mengejar keuntungan. Kata Kunci: negara, badan usaha milik negara, pembangunan kemaritiman
\end{abstract}

\begin{abstract}
National development carried out by the state covers all aspects of the life of the nation and state, including maritime development. In carrying out maritime development, the state utilizes all components it has, including utilizing StateOwned Enterprises. This article discusses the State is in the field of shipping in relation to maritime development and the role of State Owned Enterprises in the field of shipping in maritime development. To answer these problems, this research is conducted using normative legal research methods. In this normative legal research, primary legal materials, secondary legal materials, and tertiary legal materials are used. The results of the study show that state control over shipping is played by the government in the form of regulation, control and supervision. In addition, the government assigns public service obligations to State-Owned Enterprises. The assignment carried out by the State-Owned Enterprise has an important meaning in maritime development. Interestingly, the public service obligations carried out by State-Owned Enterprises in the shipping sector are positively correlated with the intent and purpose of pursuing profits.
\end{abstract}

Keywords: state, state-owned enterprises, maritime development 


\section{A. Pendahuluan}

Negara Indonesia merupakan negara kepulauan (archipelagic state) bukanlah merupakan suatu ungkapan baru, hal ini karena sejak bangsa Indonesia ada telah dikenal pernyataan tanah air sebagai penyebutan negara yang terdiri dari beriburibu pulau dengan beraneka ragam suku bangsa dan kebudayaan. Kondisi ini secara implisit sebagai pengakuan air (laut) adalah bagian integral dari wilayah negara dan merupakan pemersatu bagi pulau (daerah) dan penduduknya. ${ }^{1}$

Sebagai negara kepulauan Indonesia yang terletak pada posisi silang dua benua dan dua samudera, yakni samudera Hindia dan samudera Pasifik. Kondisi negara Indonesia tersebut menjadikan laut beserta armada dan prasarana penunjangnya merupakan syarat mutlak yang harus dimiliki (conditio sine qua non) dan merupakan faktor integratif yang membulatkan seluruh nusantara dengan segenap penghuni-penghuninya menjadi negara kesatuan yang tidak terpisah-pisahkan. Dengan kata lain laut merupakan faktor penting dan strategis dalam perwujudan wawasan nusantara yang mencakup perwujudan Kepulauan Nusantara sebagai satu kesatuan politik, satu kesatuan sosial, satu kesatuan budaya, satu kesatuan ekonomi dan satu kesatuan pertahanan keamanan. ${ }^{2}$
Dalam kedudukan sebagai penghubung satu pulau dengan pulau lainnya, maka perhubungan melalui laut berperan sebagai tulang punggung dalam perekonomian nasional, serta sebagai faktor penunjang pembangunan nasional. ${ }^{3}$ Oleh karena itu negara perlu memperhatikan dan menjadikan pembangunan perhubungan melalui laut secara baik, terpadu, dan komperehensif. Untuk itu negara harus mempergunakan segala sarana yang dimiliki untuk menunjang pembangunan kemaritiman. Termasuk mendayagunakan Badan Usaha Milik Negara (BUMN) yang bergerak di bidang pelayaran.

Secara filosofis BUMN itu lahir sebagai wujud implementasi dari kewajiban negara memberikan kesejahteraan kepada rakyat. Membangun struktur perekonomian yang kuat, melalui bisnis yang sehat dan beretika, merupakan salah satu jalan meraih kesejahteraan. Negara tidak mungkin secara langsung menjalankan aktivitas bisnis, karena itu BUMN adalah pilihan tepat bagi negara untuk memberikan kesejahteraan kepada rakyatnya melalui penempatan modal negara di dalamnya. ${ }^{4}$

Dalam konsideran menimbang UndangUndang Nomor 19 Tahun 2003 tentang Badan Usaha Milik Negara (UU BUMN) ada 3 (tiga) hal penting berkaitan dengan keberadaan Badan Usaha Milik Negara (BUMN), yaitu: Pertama, BUMN merupakan salah satu pelaku kegiatan

1 Ch. Lubis, "Tugas dan Fungsi Kesatuan Penjaga Laut dan Pantai Dalam Penegakan Hukum di Laut" (Makalah disampaikan pada Lokakarya Peningkatan Peranan Hukum dan Perlindungan Hukum Dalam Kegiatan Perhubungan Laut, Jakarta, Indonesia, 23 Oktober 1985).

2 Achmad, "Sambutan Direktur Jenderal Perhubungan Laut pada Pembukaan Lokakarya Hukum oleh Lembaga Bina Hukum Laut dan Direktorat Jenderal Perhubungan Laut" (Pidato disampaikan pada Lokakarya Peningkatan Peranan Hukum dan Perlindungan Hukum Dalam Kegiatan Perhubungan Laut, Jakarta, Indonesia, 23 Oktober 1985).

Ibid.

4 Muchayat, Badan Usaha Milik Negara: Retorika, Dinamika dan Realita (Menuju BUMN yang Berdaya Saing) (Jakarta: Gagas Bisnis, 2010), hlm. 132-133. 
ekonomi dalam perekonomian nasional berdasarkan demokrasi ekonomi. Kedua, BUMN mempunyai peranan penting dalam penyelenggaraan perekonomian nasional guna mewujudkan kesejahteraan masyarakat. Ketiga, pelaksanaan peran Badan Usaha Milik Negara dalam perekonomian nasional untuk mewujudkan kesejahteraan masyarakat belum optimal.

Peranan BUMN dalam pembangunan kemaritiman merupakan kajian yang menarik dari berbagai sudut pandang, termasuk dari sudut pandang hukum dengan menggunakan teori negara kesejahteraan (welfare state). Untuk itu artikel ini akan mengkaji dan menganalisis 2 (dua) hal, yaitu: Pertama, bagaimana peran dan kedudukan Negara di bidang pelayaran dalam kaitannya dengan pembangunan kemaritiman. Kedua, bagaimana pengaturan dan pelaksanaan peranan Badan Usaha Milik Negara bidang pelayaran dalam pembangunan kemaritiman.

\section{B. Metode Penelitian}

Penelitian yang dipergunakan dalam penelitian ini adalah penelitian hukum normatif atau penelitian hukum kepustakaan. Sebagai suatu penelitian hukum normatif, maka penelitian ini didasarkan pada analisis terhadap norma hukum, baik hukum dalam arti peraturan perundang-undangan maupun putusan-putusan pengadilan. ${ }^{5} \quad$ Namun demikian dalam penelitian ini tidak melakukan kajian terhadap putusan pengadilan dan hanya melakukan analisis terhadap normanorma hukum yang terdapat dalam peraturan perundang-undangan saja.

Dalam penelitian ini hanya mempergunakan data sekunder saja. ${ }^{6}$ Data sekunder dalam penelitian ini meliputi bahan hukum primer, bahan hukum sekunder, dan bahan hukum tersier. Penelitian dilakukan dengan melakukan inventarisasi hukum positif sebagai kegiatan awal dan mendasar untuk melakukan penelitian dan pengkajian dalam penelitian ini. ${ }^{7}$ Bahan-bahan hukum primer adalah bahan hukum yang mengikat, terdiri dari norma dasar, peraturan dasar, peraturan perundang-undangan, yurisprudensi, dan traktat. ${ }^{8}$ Bahan hukum primer juga merupakan bahan hukum yang bersifat autoritatif artinya mempunyai otoritas. Bahan hukum primer terdiri dari perundang-undangan, catatancatatan resmi atau risalah dalam pembuatan perundang-undangan dan putusan-putusan hakim. ${ }^{9}$ Bahan-bahan sekunder berupa semua publikasi tentang hukum meliputi buku-buku teks, kamus-kamus hukum, jurnaljurnal hukum, dan komentar-komentar atas putusan pengadilan. ${ }^{10}$ Bahan hukum sekunder tersebut memberikan penjelasan mengenai bahan hukum primer, seperti rancangan undang-undang, hasil-hasil penelitian, hasil karya dari kalangan hukum. ${ }^{11}$ Sementara yang

Ronal Dworkin, Legal Research (Daedalus: Spring, 1977), hlm. 250.

6 Soerjono Soekanto dan Sri Mahmudji, Penelitian Hukum Normatif: Suatu Tinjauan Singkat (Jakarta: Radja Grafindo Persada, 2001), hlm. 14.

7 Bambang Sunggono, Metode Penelitian Hukum (Jakarta: Radja Grafindo Persada, 1997), hlm. 81.

8 Soerjono Soekanto dan Sri Mahmudji, Penelitian Hukum Normatif: Suatu Tinjauan Singkat (Jakarta: Radja Grafindo Persada, 2001), hlm. 13.

9 Peter Mahmud Marzuki, Penelitian Hukum (Jakarta: Kencana Prenada Media Group, 2008), hlm. 12.

$10 \quad$ Ibid., hlm. 12.

11 Soerjono Soekanto dan Sri Mahmudji, Penelitian Hukum Normatif: Suatu Tinjauan Singkat, (Jakarta: Radja Grafindo Persada, 2001), hlm. 13. 
dimaksud dengan bahan hukum tertier, yaitu bahan yang memberikan petunjuk maupun penjelasan terhadap bahan hukum primer dan sekunder, seperti kamus, ensiklopedi, indek komulatif, dan sebagainya. Bahan hukum tertier yang dipergunakan dalam penelitian ini adalah Laporan Tahunan (Annual Report) PT. Pelayaran Nasional Indonesia (Persero) dan Laporan Tahunan (Annual Report) PT. ASDP Ferry Indonesia (Persero).

\section{Pembahasan}

\section{Kedudukan Negara di Bidang Pelayaran Dalam Kaitannya dengan Pembangunan Kemaritiman}

Tujuan bernegara berdasarkan alinea keempat Pembukaan Undang-Undang Dasar 1945 adalah untuk membentuk suatu pemerintahan negara Indonesia yang melindungi segenap bangsa Indonesia dan seluruh tumpah darah Indonesia dan untuk memajukan kesejahteraan umum, mencerdaskan kehidupan bangsa dan ikut melaksanakan ketertiban dunia yang berdasarkan kemerdekaan, perdamaian abadi dan keadilan sosial. Pemerintah sendiri berperan untuk melaksanakan fungsi dan peran negara. ${ }^{12}$ Semakin luas fungsi dan peran negara maka peran pemerintah juga semakin luas jangkauannya. ${ }^{13}$

Maclver dalam The Modern State menyatakan beberapa hal penting berkaitan dengan fungsi dan peran negara, diantaranya adalah: Pertama, berkaitan dengan pelayanan yang diberikan negara. Maclver menyatakan: "the conception of the limited state gives us a surer ground of distinction. What the state should do is what, as an organ of community, it can do. What service it should render is that of which it is in fact capabel." ${ }^{14}$ Kedua, pelayanan yang diberikan negara berupa pelayanan untuk kepentingan umum. Hal ini sebagaimana dinyatakan: "The area of business thus demarcated for the state includes, in short, thoses external conditions of social living which are of universal concern in view of the acknowledged objects of human desire. If we clearly grasp the character of the state as social agent, understanding it rationally as a form of service and not mystically as an ultimate power, we shall differ only in respect of the limits of its ability to render service" ${ }^{15}$

Ketiga, negara harus memberikan pelayanan ketertiban untuk mewujudkan kesejahteraan. Dalam buku tersebut dinyatakan: "Order within the community is justified only as it serve the need of the community. It is not order for the sake of order, but for the sake of protection and conservation and development. These terms sum up the universal concerns which we have seen to lie within the competence of law and therefore of the state". ${ }^{16}$

12 M. Solly Lubis, Asas-Asas Hukum Tata Negara, (Bandung: Alumni, 1982), hlm. 106, dituliskan sebagaimana dikutip berikut: "Tugas Pemerintah ini dalam UUD 1945, menurut Wirjono, tidak terperici secara katagoris, maka dapat dikatakan, menurut Wirjono, bahwa ilmu pengetahuanlah, khususnya ilmu Hukum Tata Negara pada umumnya, yang menentukan ini. Mengingat ini, maka tugas Pemerintah adalah amat luas, oeh karena meliputi semua aspek dari kehidupan rakyat. Sekedar perincian ini terdapt dalam cara pmbentukan masingmasing kementerian."

13 Jimly Asshiddiqie, Hukum Tata Negara dan Pilar-Pilar Demokrasi, (Jakarta: Sinar Grafika, 2012), hlm. 41.

14 Robert M. MacIVER, The Modern State, (London: Oxford University Press, s.a), hlm. 183.

15 Ibid, hlm. 183.

$16 \quad$ Ibid, hlm. 185. 
Keempat, negara melakukan penguasaan sumber-sumber kekayaan untuk mewujudkan kesejahteraan. Hal ini dalam buku tersebut dinyatakan sebagaimana dikutip berikut ini: "The state with its command of resource and its universal reach can build for the future in ways that no partial organization may attempt. It can over-rule the near selfish aims that would waste for immediate advantage the greater gifts of nature. It can carry on vast works of constructive enterprise whose benefit will be shared by future generations". ${ }^{17}$

Peran dan fungsi negara dalam pembangunan kemaritiman berkembang dari waktu ke waktu, termasuk didalamnya bidang pelayaran. Undang-Undang Nomor 17 Tahun 2008 tentang Pelayaran (UU No. 17/2008) maupun undang-undang sebelumnya, yaitu Undang-Undang Nomor 21 Tahun 1992 tentang Pelayaran (UU No. 21/1992) mengatur penguasaan negara atas pelayaran. Dalam Pasal 5 ayat (1) UU No. 17/2008 dinyatakan: "Pelayaran dikuasai oleh negara dan pembinaannya dilakukan oleh Pemerintah" dan dalam Pasal 5 ayat (1) UU No.21/1992 disebutkan: "Pelayaran dikuasai oleh negara dan pembinaannya dilakukan oleh Pemerintah." UU No. 21/1992 tentang Pelayaran mencabut sejumlah peraturan perundang-undangan peninggalan pemerintah kolonial di bidang pelayaran. ${ }^{18}$

Dalam UU No. 17/2008 terdapat sejumlah peran yang diemban pemerintahan, diantaranya adalah pembinaan pelayaran.
Berdasarkan Pasal 5 ayat (2) UU No. 17/2008, pembinaan pelayaran dilakukan pemerintah meliputi pengaturan, pengendalian, dan pengawasan. Adapun pengaturan yang dilakukan oleh pemerintah berdasarkan Pasal 5 ayat (3) UU No. 17/2008 meliputi penetapan kebijakan umum dan teknis, antara lain, penentuan norma, standar, pedoman, kriteria, perencanaan, dan prosedur termasuk persyaratan keselamatan dan keamanan pelayaran serta perizinan. Pengendalian yang dilakukan pemerintah sendiri berdasarkan Pasal 5 ayat (4) UU No. 17/2008 meliputi pemberian arahan, bimbingan, pelatihan, perizinan, sertifikasi, serta bantuan teknis di bidang pembangunan dan pengoperasian. Pengawasan yang dilakukan pemerintah menurut ketentuan Pasal 5 ayat (5) UU No. 17/2008 meliputi kegiatan pengawasan pembangunan dan pengoperasian agar sesuai dengan peraturan perundang-undangan termasuk melakukan tindakan korektif dan penegakan hukum. Pemerintah dan kewajiban pelayanan umum di sektor pelayaran secara tegas disebutkan dalam UU No. 17/2008. Pemerintah melaksanakan kewajiban angkutan di perairan untuk daerah masih tertinggal. Hal ini dapat dilihat dari ketentuan dalam Pasal 24 UU No. 17/2008 sebagaimana dikutip berikut ini:

(1) Angkutan di perairan untuk daerah masih tertinggal dan/atau wilayah terpencil wajib dilaksanakan oleh Pemerintah dan/ atau pemerintah daerah.

Ibid, hlm. 185.

18 Ibid., Ps. 31. Undang-undang ini mencabut: 1). Indische Scheepvaartswet (Staatsblad Tahun 1936 Nomor 700 ), 2). Loodsdienst Ordonnatie (Staatsblad Tahun 1927 Nomor 62), 3). Scheepmeetings Ordinnantie, (Staatsblad Tahun 1927 Nomor 210), 4). Binnenscheepen Ordonnantie (Staatsblad Tahun 1927 Nomor 289), 5). Zeebrieven en Scheepspassen Ordonnantie (Staatsblad Tahun 1935 Nomor 492), 6). Scheepen Ordonnantie (Staatsblad Tahun 1935 Nomor 66); 7). Bakengeld Ordonnantie (Staatsblad Tahun 1935 Nomor 468). 
(2) Angkutan di perairan sebagaimana dimaksud dalam pada ayat (1) dilaksanakan dengan pelayaran-perintis dan penugasan.

(3) Pelayaran-perintis sebagaimana dimaksud pada ayat (2) dilaksanakan dengan biaya yang disediakan oleh Pemerintah dan/atau pemerintah daerah.

(4) Penugasan sebagaimana dimaksud pada ayat (2) diberikan kepada perusahaan angkutan laut nasional dengan mendapatkan kompensasi dari Pemerintah dan/atau pemerintah daerah sebesar selisih antara biaya produksi dan tarif yang ditetapkan Pemerintah dan/atau pemerintah daerah sebagai kewajiban pelayanan publik.

(5) Pelayaran-perintis dan penugasan dilaksanakan secara terpadu dengan sektor lain berdasarkan pendekatan pembangunan wilayah.

(6) Angkutan perairan untuk daerah masih tertinggal dan/atau wilayah terpencil dievaluasi oleh Pemerintah dan/atau pemerintah daerah setiap tahun.

Ketentuan dalam Pasal 24 UU No. 17/2008 sebagaimana dikutip di atas merupakan landasan hukum yang mewajibkan pemerintah, baik pemerintah pusat maupun pemerintah daerah dalam pelaksanaan angkutan perairan.

Dalam Pasal 26 UU No. 17/2008 dinyatakan ketentuan lebih lanjut mengenai pelayaran-perintis dan penugasan pada angkutan di perairan untuk daerah masih tertinggal dan/atau wilayah terpencil diatur dengan Peraturan Pemerintah. Sejalan dengan itu lahirlah Peraturan Pemerintah Nomor 20 Tahun 2010 tentang Angkutan di Perairan (PP No. 20/2010). PP No. 20/2010 ini sudah diubah dengan Peraturan Pemerintah
Nomor 22 Tahun 2011 tentang Perubahan Atas Peraturan Pemerintah Nomor 20 Tahun 2010 tentang Angkutan di Perairan (PP No. 22/2011).

Secara umum dalam Pasal 70 PP No. 20/2010 diatur kewajiban pelayanan umum yang harusnya diemban oleh pemerintah. Hal ini dinyatakan sebagaimana dikutip berikut ini:

(1) Angkutan di perairan untuk daerah masih tertinggal dan/atau wilayah terpencil dilaksanakan oleh Menteri, gubernur, dan/ atau bupati/walikota.

(2) Angkutan di perairan sebagaimana dimaksud pada ayat (1) dilaksanakan dengan pelayaran-perintis dan penugasan.

(3) Kegiatan pelayaran-perintis dan penugasan sebagaimana dimaksud pada ayat (2) dilaksanakan oleh pelaksana kegiatan yang bergerak di bidang:
a. angkutan laut;
b. angkutan sungai dan danau; atau
c. angkutan penyeberangan.

Berdasarkan ketentuan Pasal 70 PP No.20/2010, pelaksanaan angkutan dilaksanakan oleh menteri, gubernur dan bupati/ walikota, baik dalam bentuk pelayanan perintis maupun penugasan kewajiban pelayanan umum.

Namun secara khusus berkaitan dengan kewajiban pelayanan umum dalam Pasal 75 PP No. 20/2010 dinyatakan sebagaimana dikutip berikut ini:

(1) Penugasan sebagaimana dimaksud dalam Pasal 70 ayat (2) dilakukan untuk:

a. menjamin kesinambungan pelayanan angkutan di perairan;

b. membantu masyarakat untuk memenuhi kebutuhan angkutan di perairan; dan 
c. memperlancar arus mobilisasi penumpang dan barang.

(2) Penugasan sebagaimana dimaksud pada ayat (1) diberikan kepada perusahaan angkutan laut nasional dengan mendapatkan kompensasi dari Pemerintah dan/atau pemerintah daerah sebesar selisih antara biaya produksi dan tarif yang ditetapkan Pemerintah dan/atau pemerintah daerah sebagai kewajiban pelayanan publik.

(3) Tarif sebagaimana dimaksud pada ayat (2) ditetapkan oleh:

a. Menteri, untuk tarif penumpang kelas ekonomi:

1. angkutan laut;

2. angkutan sungai dan danau antarprovinsi dan antarnegara; dan

3. angkutan penyeberangan antarprovinsi dan antarnegara;

b. gubernur, untuk tarif penumpang kelas ekonomi:

1. angkutan sungai dan danau antarkabupaten/kota dalam satu provinsi; dan

2. angkutan penyeberangan antarkabupaten/kota dalam satu provinsi;

c. bupati/walikota, untuk tarif penumpang kelas ekonomi:

1. angkutan sungai dan danau dalam kabupaten/kota; dan

2. angkutan penyeberangan dalam kabupaten/kota.

(4) Dalam hal penugasan untuk angkutan sungai dan danau serta angkutan penyeberangan, pelaksanaannya diberikan kepada perusahaan angkutan di perairan yang memiliki izin usaha di bidang angkutan sungai dan danau serta angkutan penyeberangan.

Ketentuan Pasal 75 PP No. 20/2010 menentukan batasan kewenangan menteri, gubernur, dan bupati/walikota dalam penetapan tarif penumpang ekonomi. Selain itu juga mengatur perusahaan angkutan laut nasional dengan mendapatkan kompensasi dari Pemerintah dan/atau pemerintah daerah sebesar selisih antara biaya produksi dan tarif yang ditetapkan Pemerintah dan/ atau pemerintah daerah sebagai kewajiban pelayanan publik.

Sebelumnya dalam Peraturan Pemerintah Nomor 82 Tahun 1999 tentang Angkutan di Perairan (PP No. 82/1999) tidak dikenal kewajiban pelayanan umum. Hanya saja dalam PP No. 82/1999 dikenal angkutan perintis. Angkutan perintis sendiri dalam peraturan pemerintah tersebut diatur sebagai berikut:

Pertama, berkaitan dengan jenis angkutan perintis, kegiatan dan kriteria angkutan perintis. Dalam Pasal 17 PP No. 82/1999 dinyatakan sebagai berikut:

(1) Angkutan perintis di perairan meliputi:
a. angkutan laut perintis;
b. angkutan sungai dan danau perintis;
c. angkutan penyeberangan perintis.

(2) Penyelenggaraan angkutan laut perintis dilakukan untuk:

a. menghubungkan daerah-daerah terpencil dan/atau belum berkembang;

b. menghubungkan daerah yang moda transportasi lainnya belum memadai;

c. menghubungkan daerah yang secara komersial belum menguntungkan untuk dilayani oleh penyelenggara angkutan laut; 
(3) Kriteria daerah terpencil dan/atau belum berkembang sebagaimana dimaksud pada ayat (2) meliputi:

a. daerah yang belum dilayani oleh perusahaan angkutan di perairan yang beroperasi secara tetap dan teratur; atau

b. daerah tersebut secara komersial belum menguntungkan untuk pelayanan angkutan; atau

c. daerah yang tingkat pendapatan perkapita sangat rendah.

(4) Ketentuan lebih lanjut mengenai angkutan perintis di perairan sebagaimana dimaksud pada ayat (1) diatur dengan Keputusan Menteri.

Ketentuan sebagaimana disebutkan di atas menunjukkan penyelenggaraan kegiatan pelayaran sebagai bagian dari upaya pemerintah dalam pembangunan kemaritiman.

Kedua, berkaitan dengan penyelenggaraan angkutan perintis itu sendiri. Dalam Pasal 18 PP No. 82/1999 dinyatakan sebagai berikut ini:

(1) Penyelenggaraan angkutan perintis di perairan sebagaimana dimaksud dalam Pasal 17 dilakukan oleh Pemerintah.

(2) Dalam menyelenggarakan angkutan perintis di perairan sebagaimana dimaksud pada ayat (1), Menteri dapat menunjuk perusahaan angkutan laut nasional, perusahaan angkutan sungai dan danau serta perusahaan angkutan penyeberangan.

(3) Dalam penyelenggaraan angkutan perintis di perairan sebagaimana dimaksud pada ayat (1), Pemerintah memberikan kompensasi/subsidi terhadap biaya pengoperasian kapal angkutan perintis.

(4) Besarnya kompensasi/subsidi sebagaimana dimaksud pada ayat (3) adalah selisih biaya yang dikeluarkan oleh perusahaan angkutan dengan pendapatan/ penghasilan dari pengoperasian angkutan perintis tersebut.

(5) Ketentuan lebih lanjut mengenai penyelenggaraan angkutan perintis di perairan sebagaimana dimaksud pada ayat (1), ayat (2) dan ayat (3) diatur dengan Keputusan Menteri.

Ketentuan Pasal 18 tersebut menunjukkan keterkaitan antara pemerintah dengan perusahaan angkutan laut nasional serta hak dan kewajiban antara keduanya.

Sebelumnya dalam Peraturan Pemerintah Nomor 17 Tahun 1988 tentang Penyelenggaraan Usaha Angkutan Laut (PP No. 17/1988) tidak mengatur kewajiban pelayanan umum pada sektor pelayaran. Sebelumnya lagi dalam Peraturan Pemerintah Nomor 2 Tahun 1969 tentang Penyelenggaraan dan Pengusahaan Angkutan Laut (PP No. 2/1969), sebagaimana telah diubah dengan Peraturan Pemerintah Nomor 25 Tahun 1985 juga tidak mengatur kewajiban pelayanan umum pada sektor pelayaran.

Undang-Undang Nomor 17 Tahun 2008 tentang Pelayaran (UU No. 17/2008) mengatur kewajiban pelayanan umum pada sektor pelayaran. Dalam Pasal 24 UU No. 17/2008 dinyatakan:

(1) Angkutan di perairan untuk daerah masih tertinggal dan/atau wilayah terpencil wajib dilaksanakan oleh Pemerintah dan/ atau pemerintah daerah.

(2) Angkutan di perairan sebagaimana dimaksud dalam pada ayat (1) dilaksanakan dengan pelayaran-perintis dan penugasan.

(3) Pelayaran-perintis sebagaimana dimaksud pada ayat (2) dilaksanakan dengan biaya 
yang disediakan oleh Pemerintah dan/ atau pemerintah daerah.

(4) Penugasan sebagaimana dimaksud pada ayat (2) diberikan kepada perusahaan angkutan laut nasional dengan mendapatkan kompensasi dari Pemerintah dan/atau pemerintah daerah sebesar selisih antara biaya produksi dan tarif yang ditetapkan Pemerintah dan/atau pemerintah daerah sebagai kewajiban pelayanan publik.

(5) Pelayaran-perintis dan penugasan dilaksanakan secara terpadu dengan sektor lain berdasarkan pendekatan pembangunan wilayah.

(6) Angkutan perairan untuk daerah masih tertinggal dan/atau wilayah terpencil dievaluasi oleh Pemerintah dan/atau pemerintah daerah setiap tahun.

Berdasarkan pengaturan dalam peraturan perundang-undangan sebagaimana dikutip di atas, memperlihatkan negara memiliki peran dan fungsi penguasaan atas pelayaran. Peran dan fungsi dari penguasaan negara atas pelayaran diemban oleh pemerintah (baik pemerintah pusat maupun pemerintah daerah) dalam sejumlah kewajiban-kewajiban. Kewajiban-kewajiban tersebut merupakan bagian dari pembangunan kemaritiman yang diemban oleh Negara.
Penguasan negara tersebut sejalan dengan teori negara kesejahteraan (welfare state) yang dikemukan oleh Mac Iver sebagaimana telah disebutkan sebelumnya. Dimana negara melakukan penguasaan dalam rangka mewujudkan kesejahteraan warga negaranya.

\section{Peranan Badan Usaha Milik Negara Bidang Pelayaran Dalam Pembangunan Kemaritiman.}

Mendirikan BUMN merupakan salah satu peran nyata pemerintah dalam ikut mengembangkan ekonomi Indonesia, yang ditujukan menjadi agent of development serta mengambil posisi motif mencari keuntungan bagi negara. ${ }^{19}$ Pembentukan BUMN adalah sebagai salah satu instrumen negara yang mempunyai motif mencari keuntungan dan juga menjalankan perannya untuk memberikan pelayanan kepada masyarakat yang tidak dapat diberikan oleh lembagalembaga pemerintah karena akan terbentur oleh regulasi yang berlaku di lembaga pemerintahan sendiri. ${ }^{20}$

Secara normatif ${ }^{21}$ maksud dan tujuan pendirian BUMN berdasarkan UndangUndang Nomor 19 Tahun 2003 tentang BUMN (UU BUMN) ${ }^{22}$ adalah: pertama, memberikan sumbanganbagiperkembangan perekonomian nasional pada umumnya dan penerimaan negara pada khususnya; ${ }^{23}$ kedua, mengejar

19 Bahrul Akbar, BUMN dan Kesejahteraan Rakyat Penelitian Hukum (Jakarta: Pusat Kajian Keuangan Negara, 2014), hlm. xiii.

20 Ibid.

21 Tim Penyusun Kamus Pusat Bahasa, Kamus Bahasa Indonesia, (Jakarta: Pusat Bahasa Departemen Pendidikan Nasional, 2008), hlm. 1078. Dalam kamus tersebut disebutkan: "normatif adjectiva berpegang teguh pd norma: seorang ahli hukum yg baik pasti "

22 Indonesia, Undang-Undang Badan Usaha Milik Negara, Ps. 2 ayat (1).

23 Ibid., Penjelasan atas Ps. 2 ayat (1) huruf a menyebutkan: "BUMN diharapkan dapat meningkatkan mutu pelayanan pada masyarakat sekaligus memberikan kontribusi dalam meningkatkan pertumbuhan ekonomi nasional dan membantu penerimaan keuangan negara." 
keuntungan; ${ }^{24}$ ketiga, menyelenggarakan kemanfaatan umum berupa penyediaan barang dan/atau jasa yang bermutu tinggi dan memadai bagi pemenuhan hajat hidup orang banyak; ; keempat, menjadi perintis kegiatan usaha yang belum dapat dilaksanakan oleh sektor swasta dan koperasi; ${ }^{26}$ kelima, turut aktif memberikan bimbingan dan bantuan kepada pengusaha golongan ekonomi lemah, koperasi dan masyarakat. Maksud dan tujuan pendirian BUMN sebagaimana termaktub dalam UU BUMN ini menunjukkan bahwa BUMN memiliki peranan dalam pembangunan nasional.

Menyelenggarakan kemanfaatan umum berupa penyediaan barang dan/atau jasa yang bermutu tinggi dan memadai bagi pemenuhan hajat hidup orang banyak selama ini diemban oleh BUMN berupa kewajiban pelayanan umum (public service obligation). BUMN bidang pelayaran juga mengemban penugasan kewajiban pelayanan umum (public service obligation).

Penugasan pada BUMN harus mempertimbangkan dua aspek penting, yaitu aspek kepedulian (going concern) terhadap perusahaan dan aspek tercapainya sasaran kewajiban pelayanan umum (public service obligation). Untuk mengetahui mengenai sejauh mana pencapaian sasaran keberhasilan kewajiban pelayanan umum (public service obligation), dapat dilakukan melalui monitoring pelaksanaan prinsip 5 tepat, yaitu tepat waktu, sasaran, kualitas, kuantitas dan harga dari kewajiban pelayanan umum (public service obligation) tersebut. Sementara untuk mengetahui aspek going concern dapat dilakukan melalui monitoring terhadap perkembangan indikator-indikator korporasi yang lazim. ${ }^{27}$

Kewajiban pelayanan umum (public service obligation) pada BUMN bidang pelayaran diatur lebih lanjut dalam Peraturan Pemerintah Nomor 20 Tahun 2010 tentang Angkutan di Perairan (PP No. 20/2010). Dalam Pasal 75 ayat (2) PP No.20/2010 dinyatakan bahwa penugasan diberikan kepada perusahaan angkutan laut nasional dengan mendapatkan kompensasi dari Pemerintah dan/atau pemerintah daerah sebesar selisih antara biaya produksi dan tarif yang ditetapkan Pemerintah dan/atau pemerintah daerah sebagai kewajiban pelayanan publik.

24 Ibid., Penjelasan atas Ps. 2 ayat (1) huruf b menyebutkan: "Meskipun maksud dan tujuan Persero adalah untuk mengejar keuntungan, namun dalam hal-hal tertentu untuk melakukan pelayanan umum, Persero dapat diberikan tugas khusus dengan memperhatikan prinsip-prinsip pengelolaan perusahaan yang sehat. Dengan demikian, penugasan pemerintah harus disertai dengan pembiayaannya (kompensasi) berdasarkan perhitungan bisnis atau komersial, sedangkan untuk Perum yang tujuannya menyediakan barang dan jasa untuk kepentingan umum, dalam pelaksanaannya harus memperhatikan prinsip-prinsip pengelolaan perusahaan yang sehat."

25 Ibid., Penjelasan atas Ps. 2 ayat (1) huruf c menyebutkan: "Dengan maksud dan tujuan seperti ini, setiap hasil usaha dari BUMN, baik barang maupun jasa, dapat memenuhi kebutuhan masyarakat."

26 Ibid., Penjelasan atas Ps. 2 ayat (1) huruf d menyebutkan: "Kegiatan perintisan merupakan suatu kegiatan usaha untuk menyediakan barang dan/atau jasa yang dibutuhkan oleh masyarakat, namun kegiatan tersebut belum dapat dilakukan oleh swasta dan koperasi karena secara komersial tidak menguntungkan. Oleh karena itu, tugas tersebut dapat dilakukan melalui penugasan kepada BUMN. Dalam hal adanya kebutuhan masyarakat luas yang mendesak, pemerintah dapat pula menugasi suatu BUMN yang mempunyai fungsi pelayanan kemanfaatan umum untuk melaksanakan program kemitraan dengan pengusaha golongan ekonomi lemah."

27 Eddy Satriya, Dengan PSO menjembatani Kesenjangan Infrastruktur (Jakarta: Kemenko Bidang Perekonomian, 2007), hlm. 8. 
Selain itu kewajiban pelayanan umum oleh BUMN di bidang pelayaran juga diatur dalam Peraturan Presiden Nomor 106 Tahun 2015 tentang Penyelenggara Kewajiban Pelayanan Publik Untuk Angkutan Barang di Laut (Perpres No. 106/2015). Dalam Perpres No. 106/2015 ini menyebutkan beberapa hal berkaitan dengan kewajiban pelayan umum, diantaranya adalah sebagai berikut:

Pertama, pertimbangan pemberian kewajiban pelayanan umum. Dalam konsideran menimbang huruf a Perpres No. 106/2015 dinyatakan sebagai berikut: "bahwa dalam rangka menjamin kesediaan barang dan untuk mengurangi disparitas harga bagi masyarakat serta untuk menjamin kelangsungan pelayanan penyelenggaraan angkutan barang ke daerah tertinggal, terpencil, terluar, dan perbatasan dalam mendukung pelaksanaan tol laut, perlu adanya penugasan kepada Badan Usaha Milik Negara yang bergerak di bidang angkutan laut yang dinilai mampu untuk menyelenggarakan kewajiban pelayanan publik."

Kedua, pengertian kewajiban pelayanan umum. Dimana dalam Pasal 1 angka 1 Perpres No. 106/2015 disebutkan: "Penyelenggaraan Kewajiban Pelayanan Publik (Public Service Obligation/PSO) untuk Angkutan Barang di Laut adalah pelaksanaan pelayaran angkutan barang ke daerah tertinggal, terpencil, terluar, dan perbatasan sesuai dengan trayek yang telah ditetapkan, dengan tetap memperhatikan dan menjaga keselamatan serta keamanan pelayaran."

Ketiga, pelaksana kewajiban pelayanan umum. Dalam Pasal 4 Perpres No.
106/2015 dinyatakan sebagai berikut: “(1) Penyelenggaraan kewajiban pelayanan publik untuk angkutan barang di laut diselenggarakan oleh Pemerintah sebagaimana dimaksud dalam Pasal 2 ayat (1) yang pelaksanaannya ditugaskan kepada Badan Usaha Milik Negara di bidang angkutan laut. (2) Pemerintah memberikan penugasan sebagaimana dimaksud pada ayat (1) kepada PT. Pelayaran Nasional Indonesia (Persero). (3) Apabila diperlukan penugasan kepada Badan Usaha Milik Negara lain di bidang angkutan laut, penugasannya ditetapkan oleh Menteri."

Selain itu Perpres No. 106/2015 mengaturjuga tatacara pelaksanaan kewajiban pelayanan umum di bidang pelayaran. Sebelumnya dalam Undang-Undang Nomor 21 Tahun 1992 tentang Pelayaran (UU No.21/1992) tidak mengatur kewajiban pelayanan umum di sektor pelayaran. Dalam Pasal 26 ayat (1) UU No.21/1992 dalam kaitan dengan BUMN hanya dinyatakan bahwa: "Penyelenggaraan pelabuhan umum dilaksanakan oleh Pemerintah dan pelaksanaannya dapat dilimpahkan kepada badan usaha milik negara yang didirikan untuk maksud tersebut berdasarkan peraturan perundang-undangan yang berlaku."

Sejalan dengan penugasan pemerintah kepada BUMN dalam bentuk kewajiban pelayanan umum (public service obligation), maka penugasan tersebut dapat diuraikan sebagai berikut:

Pertama, PT. Pelayaran Nasional Indonesia (Persero) ${ }^{28}$ ditugaskan oleh pemerintah untuk

28 PT. Pelayaran Nasional Indonesia (Persero), Laporan Tahunan 2017 PT. Pelayaran Nasional Indonesia (Persero), (Jakarta: PT. Kereta Api (Persero), 2018), hal. 68. Dalam Laporan Tahunan 2017 tersebut dituliskan sebagaimana dikutip berikut ini: "Sesuai Anggaran Dasar Perusahaan, maksud dan tujuan perseroan yaitu 
menyediakan jasa kapal laut kelas ekonomi. ${ }^{29}$ Adapun nilai kewajiban pelayanan umum yang dibebankan kepada PT. Pelayaran Nasional Indonesia (Persero) dapat dilihat pada diagram berikut ini: atau pengurangan. Untuk tahun 2006 sebesar 679,6 milyar rupiah, tahun 2007 sebesar 677,6 milyar rupiah, tahun 2008 sebesar 790 milyar rupiah, tahun 2009 sebesar 845 milyar rupiah, tahun 2010 sebesar 600 milyar rupiah,

Diagram 1. Nilai Kewajiban Pelayanan Umum (Public Service Obligation) yang diemban oleh PT. Pelayaran Nasional Indonesia (Persero) (dalam rupiah dan milyar)

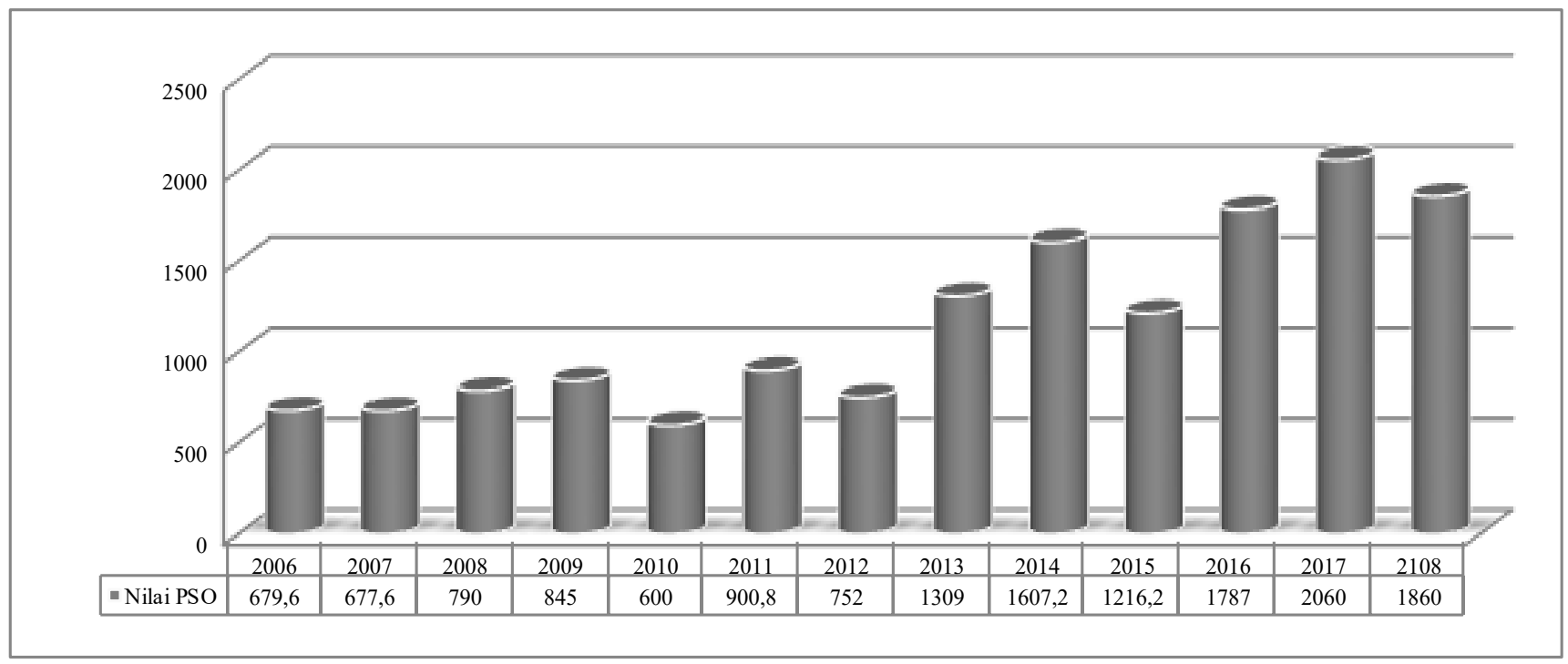

Sumber: Tim Keasdepan Data dan Teknologi Informasi Kementerian BUMN.

Berdasarkan diagram di atas nilai kewajiban pelayanan umum yang diemban oleh PT. Pelayaran Nasional Indonesia (Persero) adakalanya mengalami penambahan tahun 2011 sebesar 900,8 milyar rupiah, tahun 2012 sebesar 752 milyar rupiah, tahun 2013 sebesar 1.309 milyar rupiah, tahun 2014 sebesar 1.607,2 milyar rupiah, tahun 2015

untuk turut serta melaksanakan dan menunjang kebijaksanaan dan program pemerintah di bidang ekonomi dan pembangunan nasional pada umumnya serta pembangunan di bidang pelayaran dalam dan luar negeri untuk angkutan penumpang, hewan dan barang dalam bentuk unit curah kering atau cair dengan menerapkan prinsip-prinsip perseroan terbatas. Sesuai dengan maksud dan tujuan pendirian Perseroan, kegiatan usaha yang diselenggarakan oleh PT PELNI (Persero) adalah: a. kegiatan usaha jasa pengangkutan penumpang dan barang dengan jaringan pelayaran berjadwal maupun pelayaran yang melayani permintaan tertentu; b. kegiatan usaha jasa keagenan usaha pelayaran; c. kegiatan usaha jasa operasi terminal, pergudangan, angkutan rede, dan ekspedisi/forwarding; d. kegiatan usaha jasa pemeliharaan kapal dan usaha dok/reparasi kapal; e. kegiatan charter dan broker kapal; e. kegiatan jasa konsultan, pendidikan, pelatihan, dan pelayanan kesehatan."

29 “Kegiatan Usaha," https://www.pelni.co.id/profile/show/11, diakses 19 Februari 2016. Dimana disebutkan: "Usaha pokok PT Pelayaran Nasional Indonesia adalah menyediakan jasa angkutan transportasi laut yang meliputi jasa angkutan penumpang dan jasa angkutan muatan barang antar pulau.... PT Pelni melaksanakan tanggung jawabnya dengan tidak hanya terbatas melayari route komersial, tetapi juga melayani pelayaran dengan route pulau-pulau kecil terluar (Pepres No.78 tahun 2005 tentang Pengelolaan Pulau-pulau Kecil Terluar). Disamping itu pemanfaatkan sumber daya alam dalam rangka pembangunan yang berkelanjutan dan pemberdayaan masyarakat dalam rangka peningkatan kesejahteraan dapat tercapai sesuai target sasaran." 
sebesar 1.216,2 milyar rupiah, tahun 2016 sebesar 1.787 milyar rupiah,, ${ }^{30}$ tahun 2017 sebesar 2.060 milyar rupiah, dan tahun 2018 sebesar 1.860 milyar rupiah. ${ }^{31}$ Pengurangan nilai kewajiban pelayanan umum pada PT. Pelayaran Nasional Indonesia (Persero) terjadi pada tahun 2007, 2010, 2012, 2015, dan 2018.

Selain mengemban kewajiban pelayanan umum (public service obligation), PT. Pelayaran
Nasional Indonesia (Persero) memiliki maksud dan tujuan mengejar keuntungan (profit oriented). Untuk mendukung maksud dan tujuan mengejar keuntungan (profit oriented), PT. Pelayaran Nasional Indonesia (Persero) memiliki 3 (tiga) anak perusahaan. Adapun entitas anak perusahaan, bidang usaha, persentase kepemilikan saham entitas anak perusahaan PT. Pelayaran Nasional Indonesia (Persero) adalah sebagai berikut:

Tabel. Entitas Anak Perusahaan, Bidang Usaha, dan Kepemilikan Saham oleh PT. Pelayaran Nasional Indonesia (Persero)

\begin{tabular}{llc}
\hline \multicolumn{1}{c}{$\begin{array}{c}\text { Entitas Anak } \\
\text { Perusahaan }\end{array}$} & \multicolumn{1}{c}{ Bidang Usaha } & Kepemilikan Saham \\
\hline $\begin{array}{l}\text { PT Sarana Bandar } \\
\text { Nasional (SBN) }\end{array}$ & $\begin{array}{l}\text { Angkutan transportasi, bongkar muat, pengiriman } \\
\text { barang, pergudangan, operator terminal laut, truk, } \\
\text { custom clearance, pedalaman depo. }\end{array}$ & $99,47 \%$ \\
\hline $\begin{array}{l}\text { PT Pelita Indonesia } \\
\text { Djaya Corp (PIDC) }\end{array}$ & $\begin{array}{l}\text { Jasa perdagangan umum, perusahaan pengutusan } \\
\text { kepabeanan, jasa kebersihan, jasa pengamanan, jasa } \\
\text { pengelolaan kasur, jasa penyediaan air minum dalam } \\
\text { kemasan, jasa pengelolaan hotel, jasa penyediaan } \\
\text { hiburan atas kapal. }\end{array}$ & $99,50 \%$ \\
\hline PT Rumah Sakit & Rumah Sakit & $99,96 \%$ \\
PELNI & & \\
\hline
\end{tabular}

Sumber: Laporan Tahunan 2017 PT. Pelayaran Nasional Indonesia (Persero)

30 "PT Pelni Penyelenggara PSO Angkutan Barang di Laut", http://www. tribunnews. com/bisnis/2015/11/11/ pt-pelni-penyelenggara-pso-angkutan-barang-di-laut, diakses 11 Februari 2016. Diberitakan: "Pemerintah menugaskan perusahaan pelayaran nasional PT PELNI (persero) sebagai badan penyelenggaran Kewajiban Pelayanan Publik (Public Service Obligation - PSO) angkutan barang di laut. Penugasan tersebut tertuang dalam Peraturan Presiden No.106 Tahun 2015 tentang Penyelenggaraan Kewajiban Palayanan Publik Untuk Angkutan Barang di Laut."

31 "PSO Pelni 2018 Menurun", https://republika.co.id/berita/ekonomi/korporasi/18/02/26/ p4r1yo383-psopelni-2018-menurun, diakses 27 Februari 2018. Diiberitakan: "Kewajiban Pelayanan Publik Bidang Angkutan Laut untuk Penumpang Kelas Ekonomi Tahun Anggaran 2018 atau dikenal juga sebagai Public Service Obligation (PSO) yang diserahkan kepada PT Pelayaran Nasional Indonesia (Pelni) dari pemerintah menurun. Alokasi PSO Pelni pada tahun ini hanya sebesar Rp 1,86 triliun atau turun dari nilai PSO 2017 yang mencapai Rp 2,06 triliun." Lihat: "Pelni Tanda Tangan Kontrak PSO Sebesar Rp1,8 Triliun”, https://economy.okezone. com/read/2018/02/27/320/1865284/pelni-tanda-tangan-kontrak-pso-sebesar-rp1-8-triliun, diakses 27 Februari 2018. Diberitakan: “Kementerian Perhubungan dan PT Pelayaran Nasional Indonesia (Pelni) menandatangani Perjanjian Penyelenggaraan Kewajiban Pelayanan Publik Bidang Angkutan Laut untuk Penumpang Kelas Ekonomi Tahun Anggaran 2018 sebesar Rp1,8 triliun. Program yang lebih dikenal sebagai Public Service Obligation (PSO) penumpang PT Pelni tersebut diharapkan bisa memberikan layanan terbaik untuk kelas ekonomi. Direktur Lalu Lintas dan Angkutan Laut Kementerian Perhubungan (Kemenhub) Dwi Budi Sutrisno mengatakan, dana PSO sebesar Rp1,8 triliun itu akan dialokasikan untuk 26 unit kapal dengan total 266 perjalanan." 
Berdasarkan Laporan Tahunan PT. Pelayaran Nasional Indonesia (Persero), maka total aset, pendapatan usaha, laba (rugi) usaha, dan laba (rugi) usaha tahun berjalan PT. Pelayaran Nasional Indonesia (Persero) dapat dilihat pada diagram berikut ini: kemaritiman. Selain itu pengembanan kewajiban pelayanan umum (public service obligation) berdasarkan Laporan Tahunan PT. Pelayaran Nasional Indonesia (Persero) berkolerasi positif dengan maksud dan tujuan mengejar keuntungan (profit oriented). Hal

Diagram 2. Total Aset, Pendapatan Usaha, Laba (Rugi) Usaha, dan Laba (Rugi) Tahun Berjalan PT. Pelayaran Nasional Indonesia (Persero) (dalam rupiah dan juta)

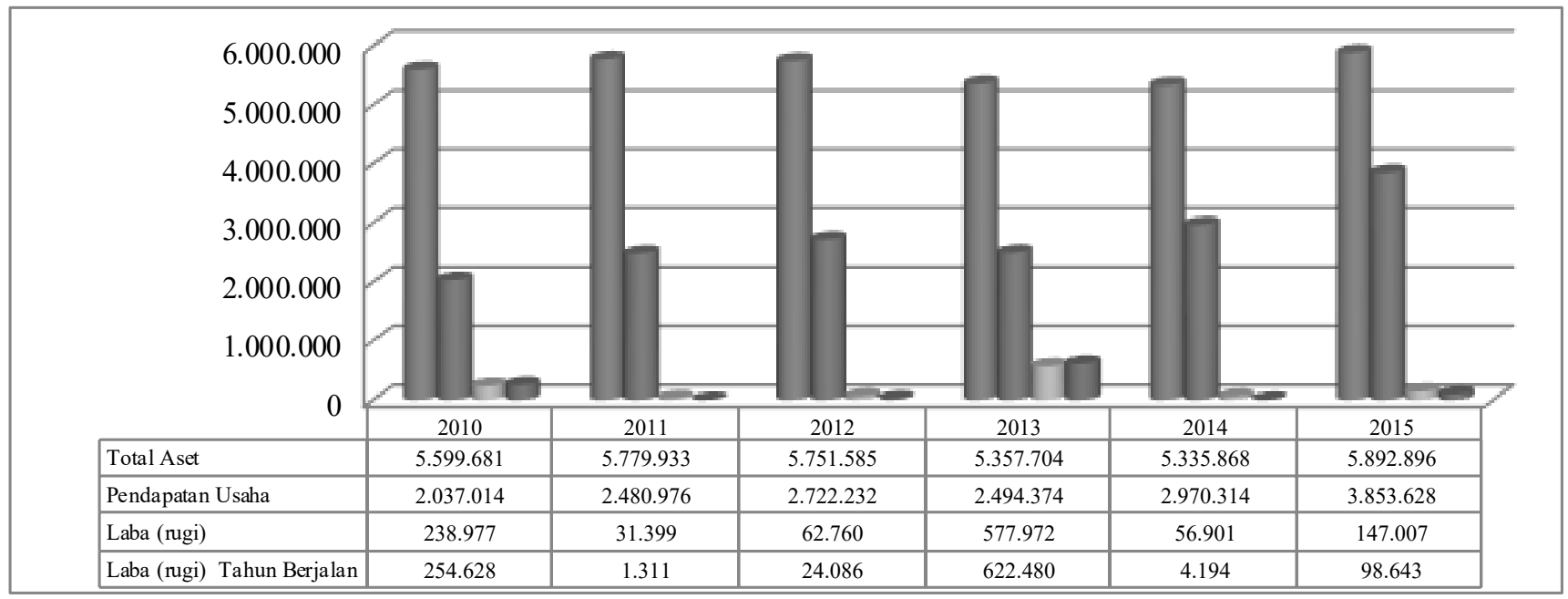

Sumber: Laporan Tahunan PT. Pelayaran Nasional Indonesia (Persero)

Kewajiban pelayanan umum (public service obligation) yang diemban oleh PT. Pelayaran Nasional Indonesia (Persero) menunjukkan bahwa BUMN bidang pelayaran memiliki peran yang sangat penting dalam pembangunan ini dapat dilihat pada tampilan total aset, pendapatan usaha, laba (rugi) usaha, dan laba (rugi) tahun berjalan sebagaimana telah ditampilkan pada Diagram 2.

32 PT. ASDP Ferry Indonesia (Persero), Laporan Tahunan 2016 PT. ASDP Ferry Indonesia (Persero), (Jakarta: ASDP Ferry Indonesia, 2017), hal. 68. Dalam Laporan Tahunan 2016 tersebut dituliskan sebagaimana dikutip berikut ini: "Sesuai dengan pasal 3 Anggaran Dasar Perusahaan maksud dan tujuan Perusahaan adalah melakukan usaha di bidang penyelenggaraan jasa pelabuhan, jasa angkutan sungai, danau dan penyeberangan dan jasa angkutan laut serta optimalisasi pemanfaatan sumber daya yang dimilki Perseroan untuk menghasilkan barang dan/ atau jasa yang bermutu tinggi dan berdaya saing kuat untuk mendapatkan / mengejar keuntungan. Untuk mencapai maksud dan tujuan tersebut perusahaan menjalankan kegiatan usaha sebagai berikut: Jasa kepelabuhan angkutan sungai, danau dan penyeberangan; Jasa angkutan sungai, danau dan penyeberangan untuk penumpang, kendaraan, barang dan hewan; Jasa angkutan laut berjadwal untuk penumpang, kendaraan, barang dan hewan; dan Jasa angkutan laut dan jasa-jasa lainnya yang berkaitan dengan jasa angkutan serta kepelabuhan sungai, danau, dan penyeberangan."

33 "Fungsi ASDP mendukung Tol Laut", http://kesehatan.kontan.co.id/news/fungsi-asdp-mendukung-tol-laut, diakses 20 Februari 2016. Dimana disebutkan: "Program tol laut yang dicanangkan Presiden Joko Widodo didukung PT ASDP Indonesia Ferry melalui pembangunan infrastruktur pelabuhan. Pemerintah pun memberi suntikan dana kepada ASDP sebesar Rp 1 triliun lewat penanaman modal negara (PMN)... Sebagai persero yang dituntut laba namun juga melakukan beberapa pekerjaan yang bersifat public service obligation (PSO), maka kemampuan mengembangkan pendapatan diluar angkutan penumpang menjadi penting." 
Kedua, PT. ASDPFerryIndonesia(Persero). ${ }^{32}$ Sejak tahun 2015 PT. ASDP Ferry Indonesia (Persero) ditugaskan oleh pemerintah untuk menyediakan jasa tranportasi penyeberangan antar sungai. ${ }^{33}$ Adapun nilai kewajiban pelayanan umum yang dibebankan kepada PT. ASDP Ferry Indonesia (Persero) dapat dilihat pada diagram berikut ini:
450 milyar. $^{34}$ Namun terdapat data dari media elektronik yang menyatakan bahwa PT. ASDP Ferry Indonesia (Persero) pada tahun 2011 juga mengemban kewajiban pelayanan umum. ${ }^{35}$

Sama halnya dengan PT. Pelayaran Nasional Indonesia (Persero), PT. ASDP Ferry Indonesia (Persero) juga memiliki maksud dan

Diagram 3. Nilai kewajiban pelayanan umum (public service obligation) yang diemban PT. ASDP Ferry Indonesia (Persero) (dalam rupiah dan milyar)

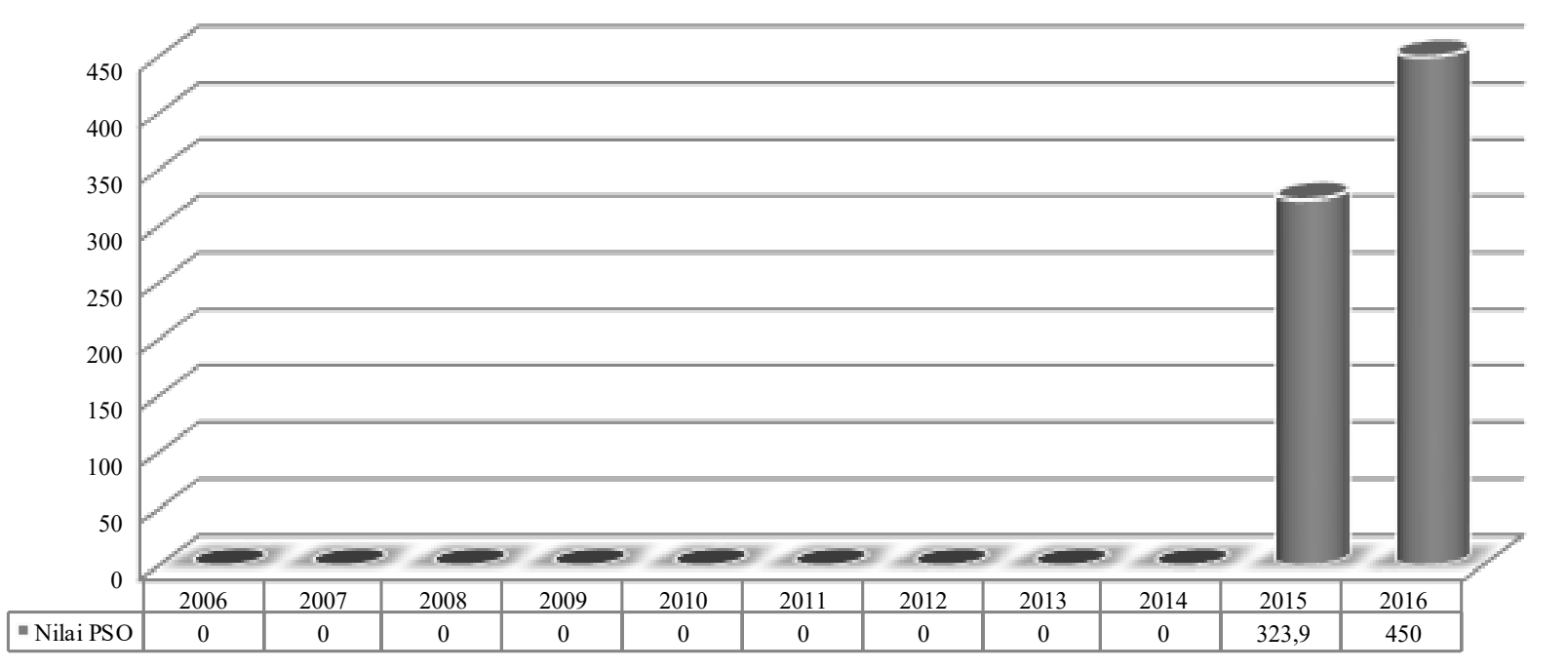

Sumber: Tim Keasdepan Data dan Teknologi Informasi Kementerian BUMN.

Adapun rincian nilai kewajiban pelayanan umum yang diemban oleh PT. ASDP Ferry Indonesia (Persero) pada tahun 2015 sebesar 323,9 milyar dan proyeksi tahun 2016 sebesar tujuan mengejar keuntungan (profit oriented). Untuk mendukung mengejar keuntungan (profit oriented), PT. ASDP Ferry Indonesia (Persero) memiliki 1(satu) anak perusahaan,

34 "Layani jalur perintis, ASDP butuh subsidi tambahan", http://nasional.kontan.co.id/ news/ layani-jalurperintis-asdp-butuh-subsidi-tambahan-1, diakses 19 Februari 2016. Disebutkan: "Perusahaan-perusahaan negara yang menjalankan pelayanan publik alias public service obligation (PSO) sudah seharusnya lebih banyak diperhatikan oleh pemerintah. Contohnya PT Angkutan Sungai Danau dan Penyeberangan (ASDP) Indonesia yang melayani jalur perintis di Kalimantan."

35 "ASDP Beli Ferry Bekas Dari Inggris", http://www.indonesiainfrastructurenews. com/2012/06/asdp-beliferry-bekas-dari-inggris/, diakses 19 Februari 2016. Disebutkan: “...Sepanjang tahun 2011, pemerintah telah mengucurkan dana PSO kepada PT ASDP Indonesia Ferry bersama PT Pelni, sebesar Rp 900 miliar.” Lihat juga, Lintasan Penyeberangan Ujung -Kamal Pasca Beroperasi Jembatan Seramadu, Newsletter Info Hubdat, Edisi Juni 2009, hal.8 dimana disebutkan: "Kapal-kapal yang tetap beroperasi dilintasan itu tentunya yang kinerjanya bagus. Pengoperasian Jembatan Suramadu juga hendak menggugah operator agar mau masuk ke penyeberangan perintis dan tidak hanya memikirkan bisnis saja. Sebagai BUMN yang mengemban misi penugasan (Public Service Obligation - PSO)." 
yaitu PT. Indonesia Ferry Properti. Persentase kepemilikan saham PT. ASDP Ferry Indonesia (Persero) pada PT. Indonesia Ferry Properti adalah 99,47 Persen. Bidang usaha entitas anak perusahaan ini adalah membangun dan mengelola hotel, marina, retail dan pelabuhan.

Berdasarkan Laporan Tahunan PT. ASDP Ferry Indonesia (Persero) bahwa total aset, pendapatan usaha, laba (rugi), dan laba (rugi) tahun berjalan PT. ASDP Ferry Indonesia (Persero) dapat dilihat pada diagram berikut ini: usaha, laba (rugi) usaha, dan laba (rugi) tahun berjalan PT. ASDP Ferry Indonesia (Persero) sebagaimana telah ditampilkan pada Diagram 4.

Kewajiban pelayanan umum (public service obligation) yang diemban oleh Badan Usaha Miliki Negara (BUMN) Bidang Pelayaran merupakan salah satu peran penting yang dilakukan BUMN tersebut dalam pembangunan kemaritiman. Penugasan yang diemban oleh BUMN tersebut dalam kaitannya dengan teori negara kesejahteraan (welfare state) Maclver merupakan suatu

Diagram 4. Total Aset, Pendapatan Usaha, Laba (Rugi), Laba (Rugi) Tahun Berjalan PT. ASDP Ferry Indonesia (Persero) (dalam rupiah dan juta)

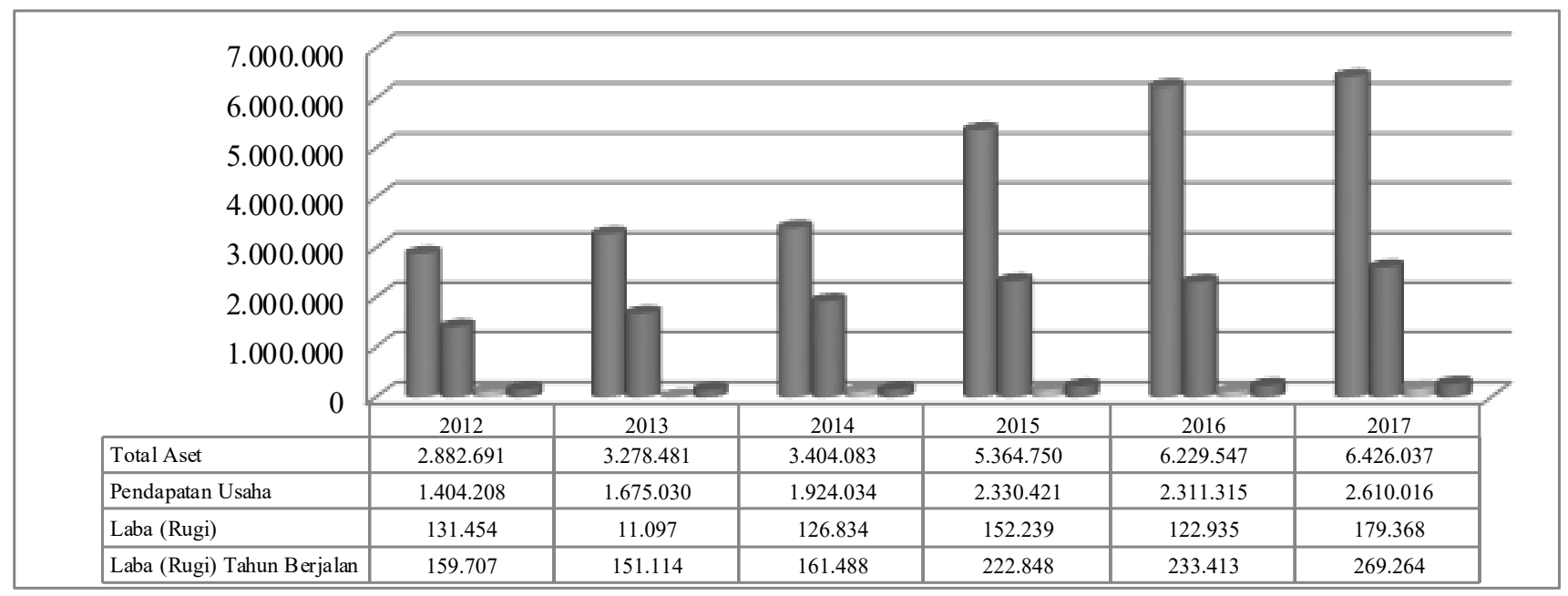

Sumber: Laporan Tahunan (Annual Report) PT. ASDP Ferry Indonesia (Persero)

Kewajiban pelayanan umum (public service obligation) yang diemban oleh PT. ASDP Ferry Indonesia (Persero), menunjukkan BUMN ini memiliki peranan dalam pembangunan kemaritiman. Selain itu kewajiban pelayanan umum (public service obligation) PT. ASDP Ferry Indonesia (Persero) berkorelasi positif terhadap maksud dan tujuan mencari keuntungan (profit oriented). Hal ini dapat dilihat pada tampilan total aset, pendapatan pelayanan yang diberikan oleh negara untuk kepentingan umum.

\section{Penutup}

Berdasarkan uraian pada bagian sebelumnya, maka dapat disimpulkan: Pertama, negara memiliki kedudukan dan peranan yang sangat penting dalam pembangunan kemaritiman. Pengaturan dalam undangundang negara memiliki hak untuk menguasai 
bidang pelayaran. Penguasaan negara atas pelayaran diperankan oleh pemerintah dalam bentuk pembinaan. Pembinaan pelayaran dilakukan pemerintah meliputi pengaturan, pengendalian, dan pengawasan. Kedua, BUMN bidang pelayaran mengemban peranan yang sangat penting dalam pembangunan kemaritiman. Hal ini dikarenakan BUMN mendapatkan penugasan dari pemerintah dalam bentuk kewajiban pelayanan umum (public service obligation). Penugasan tersebut berkorelasi positif dengan maksud dan tujuan mengejar keuntungan (profit oriented) pada BUMN.

Untuk itu disarankan pemerintah harus mengambil peran penting dalam pelayaran, karena pemerintah memiliki peran dan fungsi strategis dalam pembangunan kemaritiman. Dalam hal pemerintah memberikan penugasan kepada BUMN bidang pelayaran, pemerintah perlu memberikan kompensi yang layak kepada BUMN. Sehingga BUMN bidang pelayaran dapat mengemban penugasan kewajiban pelayanan umum (pubic service obligation) dengan baik, tanpa mengabaikan maksud dan tujuan mengejar keuntungan (profit oriented).

\section{Daftar Pustaka}

\section{Buku}

Akbar, Bahrul, BUMN dan Kesejahteraan Rakyat Penelitian Hukum (Jakarta: Pusat Kajian Keuangan Negara, 2014).

Asshiddiqie, Jimly, Hukum Tata Negara dan PilarPilar Demokrasi (Jakarta: Sinar Grafika, 2012).

Dworkin, Ronal, Legal Research (Daedalus: Spring, 1977).

Lubis, M. Solly, Asas-Asas Hukum Tata Negara (Bandung: Alumni, 1982).

MacIVER, Robert M, The Modern State, (London: Oxford University Press, s.a).
Marzuki, Peter Mahmud, Penelitian Hukum (Jakarta: Kencana Prenada Media Group, 2008).

Muchayat, Badan Usaha Milik Negara: Retorika, Dinamika dan Realita (Menuju BUMN yang Berdaya Saing) (Jakarta: Gagas Bisnis, 2010).

Satriya, Eddy, Dengan PSO menjembatani Kesenjangan Infrastruktur (Jakarta: Kemenko Bidang Perekonomian, 2007).

Soekanto, Soerjono dan Sri Mahmudji, Penelitian Hukum Normatif: Suatu Tinjauan Singkat (Jakarta: Radja Grafindo Persada, 2001).

Sunggono, Bambang, Metode Penelitian Hukum (Jakarta: Radja Grafindo Persada, 1997).

Tim Penyusun Kamus Pusat Bahasa, Kamus Bahasa Indonesia, (Jakarta: Pusat Bahasa Departemen Pendidikan Nasional, 2008).

\section{Makalah/Artikel/Prosiding/Laporan/Hasil Penelitian}

Achmad, "Sambutan Direktur Jenderal Perhubungan Laut pada Pembukaan Lokakarya Hukum oleh Lembaga Bina Hukum Laut dan Direktorat Jenderal Perhubungan Laut" (Pidato disampaikan pada Lokakarya Peningkatan Peranan Hukum dan Perlindungan Hukum Dalam Kegiatan Perhubungan Laut, Jakarta, Indonesia, 23 Oktober 1985).

Lubis, Ch., "Tugas dan Fungsi Kesatuan Penjaga Laut dan Pantai Dalam Penegakan Hukum di Laut" (Makalah disampaikan pada Lokakarya Peningkatan Peranan Hukum dan Perlindungan Hukum Dalam Kegiatan Perhubungan Laut, Jakarta, Indonesia, 23 Oktober 1985).

Newsletter Info Hubdat, Lintasan Penyeberangan Ujung -Kamal Pasca Beroperasi Jembatan Seramadu, Newsletter Info Hubdat, Edisi Juni 2009

PT. ASDP Ferry Indonesia (Persero), Laporan Tahunan 2017 PT. ASDP Ferry Indonesia (Persero), (Jakarta: PT. ASDP Ferry Indonesia (Persero), 2017).

PT. ASDP Ferry Indonesia (Persero), Laporan Tahunan 2016 PT. ASDP Ferry Indonesia (Persero), (Jakarta: PT. ASDP Ferry Indonesia (Persero), 2016).

PT. ASDP Ferry Indonesia (Persero), Laporan Tahunan 2014 PT. ASDP Ferry Indonesia (Persero), (Jakarta: PT. ASDP Ferry Indonesia (Persero), 2014). 
PT. ASDP Ferry Indonesia (Persero), Laporan Tahunan 2012 PT. ASDP Ferry Indonesia (Persero), (Jakarta: PT. ASDP Ferry Indonesia (Persero), 2012).

PT. Pelayaran Nasional Indonesia (Persero), Laporan Tahunan 2015 PT. Pelayaran Nasional Indonesia (Persero), (Jakarta: PT. Pelayaran Nasional Indonesia (Persero), 2015).

PT. Pelayaran Nasional Indonesia (Persero), Laporan Tahunan 2014 PT. Pelayaran Nasional Indonesia (Persero), (Jakarta: PT. Pelayaran Nasional Indonesia (Persero), 2014).

PT. Pelayaran Nasional Indonesia (Persero), Laporan Tahunan 2012 PT. Pelayaran Nasional Indonesia (Persero), (Jakarta: PT. Pelayaran Nasional Indonesia (Persero), 2012).

PT. Pelayaran Nasional Indonesia (Persero), Laporan Tahunan 2010 PT. Pelayaran Nasional Indonesia (Persero), (Jakarta: PT. Pelayaran Nasional Indonesia (Persero), 2010).

\section{Internet}

"ASDP Beli Ferry Bekas Dari Inggris", http://www. indonesiainfrastructurenews. com/2012/06/ asdp-beli-ferry-bekas-dari-inggris/ (diakses 19 Februari 2016).

"Fungsi ASDP mendukung Tol Laut", http:// kesehatan.kontan.co.id/news/fungsi-asdpmendukung-tol-laut (diakses 20 Februari 2016).

“Kegiatan Usaha," https://www.pelni.co.id/ profile/show/11 (diakses 19 Februari 2016).

"Layani jalur perintis, ASDP butuh subsidi tambahan", http://nasional.kontan.co.id/ news/ layani-jalur-perintis-asdp-butuh- subsidi-tambahan-1 (diakses 19 Februari 2016).

"Pelni Tanda Tangan Kontrak PSO Sebesar Rp1,8 Triliun", https://economy.okezone. com/ $\mathrm{read} / 2018 / 02 / 27 / 320 / 1865284 /$ pelni-tandatangan-kontrak-pso-sebesar-rp1-8-triliun (diakses 27 Februari 2018).

"PSO Pelni 2018 Menurun", https://republika. co.id/berita/ekonomi/korporasi/18/02 /26/ p4r1yo383-pso-pelni-2018-menurun (diakses 27 Februari 2018).

"PT Pelni Penyelenggara PSO Angkutan Barang di Laut", http://www. tribunnews. com/ bisnis/2015/11/11/pt-pelni-penyelenggarapso-angkutan-barang-di-laut, (diakses 11 Februari 2016).

\section{Peraturan}

Undang-Undang Nomor 21 Tahun 1992 tentang Pelayaran.

Undang-Undang Nomor 17 Tahun 2008 tentang Pelayaran.

Peraturan Pemerintah Nomor 17 Tahun 1988 tentang Penyelenggaraan dan Pengusahaan Angkutan Laut.

Peraturan Pemerintah Nomor 82 Tahun 1999 tentang Angkutan di Perairan.

Peraturan Pemerintah Nomor 20 Tahun 2010 tentang Angkutan di Perairan.

Peraturan Presiden Nomor 106 Tahun 2015 tentang Penyelenggara Kewajiban Pelayanan Publik Untuk Angkutan Barang di Laut. 